\title{
TEORIJA STANDARDNOGA JEZIKA D. BROZOVIĆA KAO TEMELJ U ODREĐIVANJU UKRAJINSKOGA SURŽYKA I BJELORUSKE TRASJANKE
}

\section{Uvod}

$\mathrm{D}$

ugogodišnji konvergentni razvoj genetski i strukturno srodnih jezika, ruskoga i ukrajinskoga u Ukrajini te ruskoga i bjeloruskoga u Bjelorusiji, doveli su do promjene nacionalnih obilježja na planu strukture i supstancije te oblikovanja i širenja miješanih idioma $^{1}$ poznatih pod nazivima suržy $k^{2}$ i trasjanka ${ }^{3}$. Oba idioma su posljedice neravnopravne dvojezičnosti, ukrajinsko-ruske i bjelorusko-ruske.

Mehanizmi za razvoj individualne, a zatim i masovne ukrajinsko-ruske dvojezičnosti, na području današnje Ukrajine postupno se formiraju kada dio ukrajinskog teritorija potpada pod utjecaj Moskovskoga Carstva (druga polovica 17. st.) i kada se dogodio prijelaz od staroukrajinskoga književnog jezika na tzv. slavenoruski ${ }^{4}$ (18. st.).

Ukrajinsku povijesnojezičnu zbilju obilježila je podređenost raznim geopolitičkim centrima (Centralne, Istočne i Južne Ukrajine - Ruskom Carstvu, Zapadne Ukrajine - AustroUgarskoj Monarhiji). Jezična politika u Ruskom Carstvu svela se na rusifikaciju i asimilaciju neruskih naroda, dok je jezična politika u Austro-Ugarskoj Monarhiji tolerirala, i, štoviše, poticala razvoj masovnoga polilingvizma. Na području Zapadne Ukrajine bila je dopuštena slobodna uporaba ukrajinskoga, poljskoga i rumunjskoga jezika uz službeni njemački jezik.

Nametanje načela "konvergentnoga" jezičnoga razvitka i održavanja rusko-ukrajinske dvojezičnosti u bivšem Sovjetskom Savezu dovršilo je oblikovanje suržyka i proširilo sferu njegove upotrebe.

$1 \quad$ Naziv idiom ovdje rabimo u značenju općeprihvaćenom u europskoj i hrvatskoj lingvistici, tj. kao „bilo koji oblik jezične opstojnosti: sam jezik, dijalekt, interdijalekt, mjesni govor itd.“ (Brozović 1996: 87).

2 Suř̌yk je metaforički naziv (doslovno je mješavina pšenice i raži, raži i ječma, ječma i zobi i sl. te brašno od takve mješavine, (CУM 1978: 854) za idiom koji je nastao u Ukrajini kao posljedica ukrajinsko-ruskoga diglosnoga bilingvizma.

3 Trasjanka je terminološka metafora (doslovno je to mješavina sijena i slame, koja se koristi kao stočna hrana i koja je po kakvoći lošija od sijena (Маршэўская, Піваварчык, Садоўская 2006: 26). Nastala je, slično kao i suržyk, prijenosom pojma iz svakodnevnoga života u lingvističku terminologiju i služi za označavanje idioma koji se formirao kao posljedica bjelorusko-ruskog diglosnoga bilingvizma.

$4 \quad$ Slavenoruski jezik bio je, za razliku od staroukrajinskoga, umjetna tvorevina koja se formirala na temelju crkvenoslavenskog jezika. Ukrajinski su pisci 18. stoljeća u svojim djelima svjesno ili nesvjesno, u želji da se uklope u općeruski kulturni kontekst, a zapravo tvoreći ga, jer se ruska književnost tek razvijala, prelazili iz staroukrajinskoga jezika na slavenoruski da bi ih razumjeli i u Rusiji. Utjecaj na širenje slavenoruskog jezika imala je, u određenoj mjeri, uredba o zabrani tiskanja knjiga na narječju koje se razlikuje od onoga što je prihvaćeno u Rusiji (Русанівський 2002: 131-132). 
Posljednjih osam stoljeća jezičnu situaciju u Bjelorusiji obilježilo je postojanje homogenih i homomorfnih te heterogenih i heteromorfnih skupina idioma u rangu teritorijalnih dijalekata i diglosija - službeni (državni jezik) - materinski jezik. U različitim povijesnim razdobljima sastavnice diglosije bile su i slavenski i neslavenski jezici. U doba Velike Litavske Kneževine diglosija je postojala u obliku opreke starobjeloruski jezik - bjeloruski, ukrajinski, židovski, tatarski, litavski dijalekti. Nakon Lublinske unije (1569.) poljski je jezik istisnuo starobjeloruski. Ulaskom Bjelorusije u Rusko Carstvo (posebice nakon ustanaka 1834. i 1863. godine) vodeću je ulogu preuzeo ruski jezik. U razdoblju od 1920. do 1939. godine na području zapadne Bjelorusije koja je bila u sastavu Rzeczpospolite Polske postojala je diglosija u obliku poljski jezik - dijalekti naroda koji su naseljavali ova područja (Bjelorusa, Židova, Ukrajinaca, Rusa, Litvanaca). Nakon Drugoga svjetskog rata zbog velikih promjena u strukturi stanovništva i politike BSSR-a sfera upotrebe bjeloruskoga i drugih jezika, osim ruskoga, bila je značajno ograničena, a pojedini jezici (npr. bjeloruski dijalekt jidiša) sasvim su nestali na lingvističkoj karti (Скопненко 2000).

Jezičnu situaciju u Bjelorusiji od 1998. godine određuje državni status dvaju jezika, ruskoga i bjeloruskoga, a time i službeno deklarirani masovni bilingvizam (a u praksi diglosija).

Suržyk je svojevrsna hibridna tvorevina, koja egzistira u tri njegove osnovne tipološke inačice - a) suržyk koji je oblikovan na ruskoj leksičkoj osnovici, a ortoepska i gramatička su mu obilježja ukrajinska (понял + зрозумів = поняв; вытянул + витягнув = витянув; пошел + пішов $=$ пошов; царевной + королівною $=$ царєвною; всігда; мєсто $)^{5}$, b) suržyk koji je oblikovan na ukrajinskoj leksičkoj osnovici, a ortoepska i gramatička su mu obilježja ruska (кіслий, по садам, два кілограма) i c) suržyk u kojemu su gramatička i leksička obilježja ukrajinskoga i ruskoga zastupljena naizmjenično i kaotično (suržyk - Ми под’їжжаїмо зараз до поворота; ukrajinski - Ми під’їжджаємо зараз до повороту; ruski - Мы подъезжаем сейчас к повороту).

Bjeloruska trasjanka ima bjelorusku fonetiku i oblikuje se prvenstveno gramatičkim tvorbenim morfemima bjeloruskoga jezika, dok su korijenski morfemi više podložni utjecaju ruskoga jezika (trasjanka: цясціраванне - bjeloruski: тэсціраванне, тэставанне; trasjanka: шчас - bjeloruski: зараз; trasjanka: нічаво - bjeloruski: нічога; trasjanka: очань дажа - bjeloruski: нават вельмі) ${ }^{6}$ (Fuderer 2008: 176).

Objašnjavajući prirodu hibridnoga bjelorusko-ruskoga idioma, N. Mečkouskaja definira ga kao zbroj substandardnih idiolekata koji u različitom omjeru objedinjuju osobine bjeloruskoga i ruskoga jezika (2007: 91).

Kaotičnost koja je prisutna u procesu miješanja elemenata i u suržyku i u trasjanki potvrđuje da govornici koji se služe tim idiomima ne razlikuju dva standardna jezika kao zasebne i samostalne sustave. Ukrajinski i ruski jezik te bjeloruski i ruski jezik prihvaćaju se kao zajednički, nediferencirani izvor jezičnih sredstava, kojim se služe govornici suržyka ili trasjanke i pri tome ne kontroliraju svoj govor i proizvoljno biraju i spajaju oblike obaju jezika. Zbog toga i suržyk i trasjanku možemo razmatrati kao zbroj idiolekata.

Oba su idioma tipološki slična, nastajali su stihijski, nisu kodificirani i narušavaju tradicionalnu percepciju raznih poznatih substandardnih idioma (npr. češke obecne češtine,

\footnotetext{
Navedeni primjeri najopćenitije ilustriraju pojave suržyka.

6 Primjeri trasjanke navedeni su prema Važnik 2006: 81-82.
} 
francuskoga la langue populaire, ruskoga prostorečija, talijanskoga dialetto regionale), interdijalekata, sociolekata, urbanog žargona i "miješanih" idioma - lingua franca, pidžina, kreola i sl.

Bez obzira na rasprostranjenost ovih idioma na ukrajinskom i bjeloruskom prostoru, te njihovu dugogodišnju povijest, oba su idioma postala predmetom proučavanja tek od 90-ih godina 20. stoljeća zbog osjetljivosti sociolingvističkih istraživanja u uvjetima totalitarizma i ideološkoga pritiska. Većina radova do sada posvećenih suržyku i trasjanki imaju segmentni karakter, ne zasnivaju se na detaljnoj lingvističkoj analizi korpusa i u njima se premalo pažnje posvećuje proučavanju obaju idioma u kontekstu drugih slavenskih jezika.

Cilj ovoga rada je odrediti i definirati suržyk i trasjanku na osnovi teorije standardnoga jezika D. Brozovića.

\section{Određivanje suržyka i trasjanke na osnovi Brozovićeve teorije jezične standardnosti}

Do sada su suržyk i trasjanka proučavani isključivo s gledišta sociolingvistike kao pojave unutar konkretnih država i etnosa, odnosno kao posljedice diglosnog bilingvizma. Premalo je pažnje posvećeno proučavanju obaju idioma u širem slavenskom kontekstu, s gledišta poredbene genetske i tipološke lingvistike. Zato ćemo u ovom radu te idiome pokušati odrediti primjenjujući teorijski aparat Brozovićeve teorije standardnosti jezika. Premda smo svjesni da suržyk i trasjanka ne spadaju direktno u pojave kojima se bavi genetska i tipološka lingvistika, te da su predmet proučavanja u navedenoj teoriji prije svega standardni jezici, suržyk i trasjanka kao određeni oblici postojanja jezika mogu biti klasificirani prema kriterijima koje je u svojoj teoriji opisao D. Brozović. A na tu će se klasifikaciju posve logično nadovezati usporedba standardnoga jezika sa suržykom i trasjankom prema kriterijima standardnosti razrađenima $\mathrm{u}$ teoriji.

U klasifikaciji idioma s obzirom na njihova osnovna obilježja D. Brozović primjenjuje tri kriterija:

1) organičnost/neorganičnost,

2) konkretnost/nekonkretnost,

3) viši/niži hijerarhijski stupanj (rang).

\subsection{Kriterij organičnost/neorganičnost}

Organski idiom je ,samo govor jedne socijalno čvrste etnički homogene (bez obzira na genezu), zatvorene i definirane zajednice, s određenom civilizacijskom fizionomijom, dakle govor konkretnog sela ili skupine uže povezanih sela odnosno zaselaka, ili govor... roda i sl., ali uvijek na najnižim razvojnim stupnjevima društva“ (Brozović 1970: 11). Dakle, organski su idiomi mjesni govor, dijalekt i sl.

$\mathrm{Na}$ višim razvojnim stadijima društva javlja se potreba za neorganskim jezičnim instrumentima, a organski idiomi služe kao materijal za njihovo izgrađivanje.

Među neorganske idiome ubrajaju se standardni jezici, i hijerarhijski niži idiomi - razgovorni jezik (općenacionalni ili regionalni), žargon, interdijalekt i sl. Razgovorni jezik D. 
Brozović poistovjećuje sa substandardnim idiomima, koji su „u odnosu prema govorenom vidu stanovitoga standardnog jezika deteriorni po raznim kriterijima: regionalna odstupanja od norme, inovacije bez prestiža, funkcionalne redukcije i redukcije u inventaru supstancijalnih (leksičkih) i strukturnih (gramatičkih) elemenata, kao i neodređenost i nestabilnost tih elemenata" (Brozović 1970: 12).

Takvo određenje primjenjivo je na općečeški interdijalekt (substandard), tzv. obecnu češtinu, koji je nastao kao negativna posljedica u 19. stoljeću oblikovane i ozakonjene norme oslonjene na književnojezičnu tradiciju 16. stoljeća (Sesar 2004: 71). Danas češki substandard funkcionira paralelno sa češkim standardom (spisovná čeština) i konkurira mu na općenacionalnoj razini.

Po našemu mišljenju, takvo određenje substandarda donekle može karakterizirati i suržyk i trasjanku. Iako oba idioma pokazuju za substandard tipična odstupanja od standardnoga jezika, razlika između suržyka, odnosno trasjanke i substandarda je u tome što su oba idioma rezultat miješanja dvaju srodnih jezika - ukrajinskoga i ruskoga te bjeloruskoga i ruskoga.

Dakle, prema kriteriju organičnost/neorganičnost suržyk i trasjanku valja odrediti kao neorganske idiome.

\subsection{Kriterij konkretnost/nekonkretnost}

Konkretnima D. Brozović smatra samo dvije vrste idioma: mjesni govor i standardni jezik, jer jedino oni imaju jasno definiranu strukturu i supstanciju. Ostali su idiomi nekonkretni, a ,ako se radi o organskim idiomima hijerarhijski višima od mjesnoga govora, onda su oni ne samo nekonkretni nego i apstraktni ${ }^{76 ، ~(B r o z o v i c ́ ~ 1970: ~ 12-13) . ~}$

S obzirom da je apstraktnost osobina samo neorganskih idioma najvišega ranga (standardnih jezika), suržyk i trasjanku možemo definirati kao nekonkretne idiome.

\subsection{Kriterij viši/niži hijerarhijski stupanj (rang)}

Hijerarhijski odnos postoji u oba niza idioma, u organskom i neorganskom. Među neorganskim idiomima samo je standardni jezik idiom najvišega ranga. U hijerarhiji neorganskih idioma proporcionalni su visina ranga i stupanj konkretnosti: standardni je jezik idiom najvišega ranga s najvećim stupnjem konkretnosti, nižega su ranga razgovorni jezik i/ili općenacionalni substandarni jezik, koji su nekonkretni, a najniži rang ima interdijalekt, koji je još nekonkretniji (Brozović 1970: 13).

Dakle, prema kriteriju viši/niži hijerarhijski stupanj (rang) suržyk i trasjanka su idiomi niskoga hijerarhijskog ranga.

Iz klasifikacije idiomā prema gore navedenim kriterijima proizlazi da su suržyk i trasjanka neorganski nekonkretni idiomi niskoga hijerarhijskog ranga.

U opreci kategoriji konkretnosti su abstraktnost kao polarna kategorija i nekonkretnost kao kategorija koja isključuje suprotnu. 


\section{Suržyk i trasjanka u kontekstu osobina standardnosti}

Predmet proučavanja u teoriji standardnoga jezika prije svega je standardnost jezika, odnosno osobine jezične standardnosti kao temelj za „klasifikaciju pojavne standardnosti... u jezicima sa slavenskom supstancijom i strukturom“ (Brozović 1970: 43). Međutim, u ovom smo radu utvrdili da se i suržyk i trasjanka i standardni jezik, kao specifični oblici opstojnosti jezika, ubrajaju među neorganske idiome, premda se suržyk i trasjanka polariziraju u odnosu na standardni jezik na osi konkretnosti i na hijerarhijskoj ljestvici. Stoga smatramo mogućim i potrebnim usporediti ova tri idioma u kontekstu osobina standardnosti.

\subsection{Osnovne osobine standardnosti jezika}

Za klasifikaciju standardnosti slavenskih jezika D. Brozović navodi petnaest (15) osobina koje grupira u tri skupine u obliku binarnih pitanja (Brozović 1970: 51-52). U radu donosimo preoblikovana binarna pitanja, jer smatramo da i ove kompaktne formulacije u dovoljnoj mjeri prikazuju bit osobina standardnosti.

\section{A. Način formiranja i funkcioniranje standardnih jezika}

1. Visoki/niski stupanj autonomnosti i elastične stabilnosti.

2. Koegzistencija dubleta u sustavu normi.

3. Izravni/neizravni (preko posrednika) prijelaz od standarda prema inter(dijalektima).

4. Razvoj kontinuirani/s prekidima od epohe formiranja s današnjom supstancijom i strukturom.

B. Karakter osnovice standardnog jezika i odnos prema naciji

5. Homogena/heterogena domaća dijalekatska osnovica.

6. Izravno/neizravno (podvrgnuta folklornoj stilizaciji) normirana osnovica.

7. Uzimanje kulturnog (inter)dijalekta kao osnovice.

8. Polifunkcionalnost standardnoga jezika.

9. Mogućnost primjene formule jedan (1) standardni jezik-jedna (1) nacija.

C. Odnos prema drugim standardnim jezicima

10. Domaća/s tuđim elementima dijalekatska osnovica.

11. Vlastiti/posuđeni supstancijalni elementi na kojima se formirao standard.

12. Utjecaj jednoga/nekoliko većih i razvijenijih srodnih jezika.

13. Ograničavanje/toleriranje kalkiranja u normi.

14. Prolaženje kroz fazu purizma.

15. Upotreba unutar homogene/heterogene civilizacije.

\subsection{Komparacija jezičnoga standarda sa suržykom i trasjankom prema osnovnim osobinama standardnosti}

Standardni je jezik predmet proučavanja u geneolingvistici i tipolingvistici. Suržyk i trasjanka kao pojave koje su nastale kao posljedice određene jezične politike u određenim društvenim sredinama predmeti su proučavanja u sociolingvistici. No, s obzirom na proširenost, društveno značenje i konkurentni odnos prema svojim standardnim jezicima, sama se po sebi nameće potreba da se na te idiome pogleda iz drugačijeg kuta nego do sada. 
Usporedit ćemo $^{8}$ tri idioma - standardni jezik, suržyk i trasjanku, i to isključivo prema osobinama koje se, po našem mišljenju, mogu primijeniti u određivanju suržyka i trasjanke.

(1) Osnovne su osobine standardnosti autonomnost i elastična stabilnost. One su međusobno povezane - standardni jezici s visokim stupnjem autonomije i s malim mogućnostima za svjesne intervencije, ujedno su i stabilniji. Radi se o standardnim jezicima koji su se polako izgrađivali i nisu nastali svjesnim aktom, a zbog toga ni nakon formiranja nisu bili podložni svjesnim intervencijama (npr. ruski, poljski i češki). U takvim su se standardnim jezicima supstancija (leksik) i struktura (gramatički sustav) osnovice iskristalizirali u dugim predstandardnim procesima u raznim vidovima pisanoga jezika, s konvergentnim pravcima razvoja. Takvi standardni jezici imaju različite značajke ,artificijelnosti“ i slabe značajke „organičnosti“" zbog visoke autonomije u odnosu na organske idiome (Brozović 1970: 43).

Suržyk i trasjanka formirali su se polako, nastajali su donekle svjesnim aktom - u težnji da se usvoji prestižniji ruski standard i u određenoj su mjeri bili podložni svjesnim intervencijama. Kao rezultat kaotičnoga prožimanja jezičnih supstancija i struktura dvaju genetski i tipološki srodnih jezika (ukrajinskoga i ruskoga te bjeloruskoga i ruskoga) ni jedan od ta dva idioma nema jasno iskristaliziranu supstanciju i strukturu. Oba idioma postoje samo u govornom obliku.

Dakle, ni suržyk, ni trasjanka nisu ni autonomni ni elastično stabilni idiomi.

(2) Svaki veći standard određuje postojanje zona definiranih upotrebom jedne od dviju polariziranih jezičnih dubleta, najčešće fonetskih. Kod nekih je slavenskih standardnih jezika ta pojava izražena nešto jače (praško-moravska, varšavsko-krakovska, kijevsko-lavovska zona i sl.), kod drugih slabije (Brozović 1970: 43).

$\mathrm{U}$ jezičnim kontaktima s ruskim jezikom nacionalne fonetske osobine ukrajinskoga $\mathrm{i}$ bjeloruskoga jezika nisu podlegle utjecaju ruske fonetike. Fonetsko-fonološki sustav suržyka i trasjanke je u skladu s normama nacionalnih jezika, a eventualna odstupanja moguća su zbog utjecaja vlastitih dijalekata.

Ako se različite vrste suržyka razmatraju u kontekstu tipova jezične kompetencije u uvjetima ukrajinsko-ruske dvojezičnosti, kakve predlaže ukrajinski jezikoslovac V. Trub, možemo govoriti o postojanju varijanata suržyka - 1) ukrajinsko-ruskog suržyka (kod govornika kojima je ukrajinski jezik i prvi (materinski) i osnovni (temeljni jezik, u kojemu se govornik služi najvećim brojem jezičnih podsustava), a ruski jezik nije prvi i nije osnovni) i 2) rusko-ukrajinskog suržyka (kod govornika kojima je ruski jezik i prvi (materinski) i osnovni (temeljni jezik, u kojemu se govornik služi najvećim brojem jezičnih podsustava), a ukrajinski jezik nije prvi i nije osnovni) (Ставицька, Труб 2007: 68-72).

3) Neki standardni jezici koegzistiraju sa svojim substandardom (npr. češki standardni jezik spisovná čeština i substandard obecná čeština) koji na općenacionalnoj razini može konkurirati standardnome jeziku. U takvim jezicima nema izravnoga prijelaza od konkretnoga standardnog idioma prema nižim, nekonkretnim neorganskim idiomima (Brozović 1970: 44).

S obzirom na proširenost suržyka i trasjanke i njihov konkurenti odnos prema ukrajinskom i bjeloruskom standardnom jeziku možemo govoriti o njihovoj sličnosti (ali ne i

8 Naš stav u određivanju proučavanih miješanih idioma prema osobinama standardnosti nije definitivan i ne isključuje drugačija stajališta u vezi s ovom problematikom. 
istovjetnosti) substandardu. Za razliku od substandarda koji ima više-manje istu supstanciju kao i odgovarajući standardni jezik, supstancija i struktura suržyka i trasjanke formirane su od elemenata dvaju jezika.

(4) Nakon što su jednom formirani kao konkretni sustavi s više-manje određenom supstancijom i strukturom, neki se standardni jezici, razvijaju u kontinuiranoj evoluciji, a u nekima se razvoj prekida pa se standardni jezik opet obnavlja (npr. slovenski ili u određenoj mjeri češki). Druga vrsta prekida može se dogoditi kad dođe do znatnijih neevolucijskih promjena u supstanciji (hrvatska varijanta na razmeđu 19. i 20. st.) (Brozović 1970: 44-45).

Suržyk i trasjanku obilježava određeni kontinuitet evolucije, ali zbog svoje prirode oni nisu i ne mogu biti formirani kao konkretni sustavi.

(5) „Supstancija i struktura standardnoga jezika mogu biti homogene, npr. moskovska, praška, srednjoslovačka osnovica ruskoga, češkog, slovačkoga jezika) i/ili mogu biti kontaminacija različitih elemenata, npr. malopoljska i velikopoljska komponenta u poljskome, istočnobugarska i sofijska u bugarskome i sl.“(Brozović 1970: 45).

Ukrajinski i bjeloruski standardni jezik formirani su na heterogenoj dijalekatskoj osnovici.

Istraživanja J. Ševel'ova pobijaju u sovjetskoj lingvistici ustaljenu tvrdnju o homogenoj srednjodnjeparskoj dijalekatskoj osnovici ukrajinskoga standardnoga jezika: „...українська літературна мова, власне, сміливо може бути названа мішаною щодо свосї діялектної основи, i, отже, традиційне підручникове твердження про іiі київсько-полтавську основу вимагає якщо не цілковитої ревізії, то принаймні додатку: з великим галицьким нашаруванням. Але ці нашарування так тривало відкладалися в українській мові і так органічно в неї всотані, що виділити їх з усієї системи сучасної літературної мови дуже важко. Можна піти навіть далі і висунути твердження про те, що виділити всі галицькі елементи сучасної української літературної мови - річ взагалі цілком неможлива. I схід, і захід України складали свої внески в літературну мову, не оглядаючися й не ощаджуючи. Ці внески так переплелися, що дуже часто найуважніший дослідник не може розплутати їхнього коріння. I тільки уважна аналіза мовознавця або свідчення сучасників, коли дане мовне явище сприймалося ще гостро як новина, можуть стати нам у пригоді, щоб виявити походження того чи того мовного елементу"9 (Шевельов 2003: 94-95).

Na formiranje bjeloruskoga književnoga, odnosno standardnoga jezika kroz povijest su znatno utjecali ruski, ukrajinski i poljski jezik. Međutim, po mišljenju V. Vinogradova, rezultati tih utjecaja nimalo se nisu odrazili na nacionalnoj specifičnosti bjeloruskog standardnog jezika, već suprotno - u procesu jezičnih kontakata sa spomenutim jezicima još su se više

„... ukrajinski književni jezik zapravo se s obzirom na svoju dijalektalnu osnovicu slobodno može nazvati miješanim, a tradicionalna udžbenička tvrdnja o njegovoj kijevsko-poltavskoj osnovici zahtijeva - ako ne cjelovitu reviziju, a ono barem dopunu - s brojnim galicijskim elementima. A ti su elementi tako dugo prodirali u ukrajinski jezik i tako su organski u njega urasli da ih je iz sustava suvremenoga književnoga jezika vrlo teško izdvojiti. Može se ići i dalje pa i odbaciti mišljenje da se svi galicijski elementi suvremenoga ukrajinskoga književnoga jezika uopće mogu izdvojiti. I istok i zapad Ukrajine unosili su svoje elemente $u$ književni jezik, spontano i obilato. Ti su se elementi tako isprepleli da vrlo često ni najpažljiviji istraživač ne može odrediti njihove korijene. Samo temeljita jezikoslovna analiza i svjedočenje suvremenika o tome kad je određena govorna pojava prihvaćena kao novina mogu nam pomoći u određivanju podrijetla ovoga ili onoga jezičnoga elementa“ (Ševeljov 2003: 94-95). 
aktivirali njegovi unutarnji resursi i još su se svjesnije iskristalizirala njegova nacionalna obilježja (Виноградов 1967: $59-60)$.

Suvremeni bjeloruski jezik formirao se na bazi središnjih (srednjobjeloruskih) govora. Srednjobjeloruski govori su ,najmlađi“ na području Bjelorusije. Oni čine poseban interdijalekt koji je nastao kao posljedica frontalnog uzajamnog djelovanja jugozapadnog i sjeveroistočnog narječja bjeloruskoga jezika (Скопненко 2000).

Međutim, D. Brozović određuje dijalekatsku osnovicu bjeloruskoga jezika kao homogenu (Brozović 1970: 53).

Suržyk i trasjanka su donekle formirani i na heterogenoj, miješanoj ukrajinsko-ruskoj i bjelorusko-ruskoj osnovici.

(8) Većina slavenskih jezika (osim lužičkosrpskih koje u nekim funkcijama zamjenjuje standardni njemački jezik) izvršavaju polivalentne funkcije - javne, kulturne, informativne, književne, znanstvene, prosvjetne, administrativne, privredne, komunikacijske i dr.

U tome smislu ni suržyk ni trasjanka nisu polifunkcionalni, i više su u funkciji razgovornoga jezika ${ }^{10}$.

(10) Supstancijalna baza većine slavenskih standardnih jezika izgrađena je uglavnom vlastitim elementima. U tom pogledu od prosjeka znatno odstupaju ruski i bugarski jezik jer njihova osnovica sadrži slavenske supstancijalne elemente tuđe njihovoj strukturi - crkvenoslavenske elemente (Brozović 1970: 47).

Supstancijalna baza suržyka i trasjanke izgrađena je elementima ukrajinskoga i ruskoga te bjeloruskoga i ruskoga jezika. Hibridi u suržyku nastaju na tri različita načina: 1) ruski supstancijalni elementi uokviruju se sredstvima ukrajinske ortoepije i gramatike, 2) ukrajinski supstancijalni elementi uokviruju se sredstvima ruske ortoepije i gramatike i 3) norme obaju jezika naizmjenično i kaotično se isprepliću u suržykizmima.

U trasjanki se najčešće ruski supstancijalni elementi uokviruju bjeloruskom ortoepijom i gramatikom.

(11) U procesu izgradnje vlastite supstancijalne i strukturne osnovice koja bi mogla zadovoljavati funkcije standardnoga jezika svi su slavenski jezici posuđivali supstancijalne (i rjeđe strukturne) elemente iz razvijenijih slavenskih standardnih jezika, prije svega iz ruskoga, poljskoga i češkoga. A u određenoj mjeri ti su jezici poslužili jedan drugome u iste svrhe. „Neki su slavenski standardni jezici u procesu svoga usavršavanja i prilagođavanja potrebama moderne duhovne i materijalne civilizacije znatno opteretili svoju supstanciju tuđim slavenskim elementima, npr. ukrajinski i bjeloruski ruskima i poljskima, lužičkosrpski jezici prvenstveno češkima, makedonski srpskim, bugarskim i ruskim elementima, bugarski ruskima, a drugi su se takvim elementima umjerenije služili (ruski, poljski, hrvatskosrpski, pa i češki), ili su u svojoj osnovici imali mogućnosti da tuđe elemente bolje maskiraju (slovački jezik češke), ili su tuđe elemente uzimali ravnomjerno s raznih strana i dobro ih maskirali (slovenski jezik češke, ruske i hrvatske)“ (Brozović 1970: 47-48).

Suržyk i trasjanka posuđuju iz ruskoga jezika i supstancijalne i strukturne elemente. Stupanj prožetosti suržyka i trasjanke ruskim leksičkim i gramatičkim sredstvima teško je

$10 \quad$ Zbog očuvanja u suržyku i trasjanki fonetsko-fonoloških normi (uz neznatna odstupanja u granicama dijalekata) ukrajinskoga i bjeloruskoga jezika pojedini jezikoslovci, npr. G. Cyhun, L. Stavyc'ka, T. Kuznjecova svrstavaju te idiome među razgovorne oblike opstojnosti jezikā. 
ustanoviti bez detaljne lingvističke analize tih idioma, ponajprije zbog njihove realizacije kao zbroja idiolekata.

\section{Zaključak}

Na kraju analize suržyka i trasjanke u kontekstu Brozovićeve teorije standardnoga jezika predlažemo sažetu (radnu) definiciju tih idioma:

Suržyk i trasjanka su neorganski nekonkretni idiomi niskoga hijerarhijskog ranga koji su nastali kaotičnim miješanjem dvaju srodnih jezika - ukrajinskoga i ruskoga te bjeloruskoga i ruskoga - i koji se, za razliku od ukrajinskoga i bjeloruskoga standardnog jezika, ne odlikuju ni autonomijom, ni elastičnom stabilnošću, ni polifunkcionalnošću. 